\title{
Seroprevalence and molecular characterization of Mycobacterium bovis infection in camels (Camelus dromedarius) in the Delta region, Egypt
}

\author{
Yasser F. Elnaker ${ }^{1}$, Mohmed S. Diab ${ }^{2}$, Nermin A. Ibrahim³ ${ }^{3}$ Attia El-Gedawy ${ }^{4}$ Rania Samir Zaki ${ }^{5}$ and Adel Radwan ${ }^{6}$
}

1. Department of Animal Medicine (Infectious Diseases), Faculty of Veterinary Medicine, The New Valley University, Egypt; 2. Department of Animal Hygiene and Zoonoses, Faculty of Veterinary Medicine, The New Valley University, Egypt; 3. Department of Bacteriology, Mycology and Immunology, Faculty of Veterinary Medicine, Mansoura University, Egypt; 4.Tuberculosis Unit, Animal Health Research Institute, Dokki, Egypt; 5. Department of Meat Hygiene, Faculty of Veterinary Medicine, The New Valley University, Egypt; 6. Directorate of Veterinary Medicine, Behira Governorate, Egypt.

Corresponding author: Mohmed S. Diab, e-mail: mohameddiab333@gmail.com

Co-authors: YFE: yasserelnaker@yahoo.com, NAI: nerminmousa64@yahoo.com, AE: attia31@gmail.com, RSZ: raniasamir5555@gmail.com, AR: adelradwan06@gmail.com

Received: 12-04-2019, Accepted: 21-06-2019, Published online: 05-08-2019

doi: 10.14202/vetworld.2019.1180-1187 How to cite this article: Elnaker YF, Diab MS, Ibrahim NA, El-Gedawy A, Zaki RS, Radwan A (2019) Seroprevalence and molecular characterization of Mycobacterium bovis infection in camels (Camelus dromedarius) in the Delta region, Egypt, Veterinary World, 12(8): 1180-1187.

\begin{abstract}
Aim: This study aimed to determine the prevalence rates of Mycobacterium infection in camel sera collected before slaughter and gross lesion tissue collected at postmortem (PM) using enzyme-linked immunosorbent assay (ELISA), bacteriological culture, and polymerase chain reaction (PCR). In addition, serum samples from humans who had occupational contact with camels were tested by ELISA and sputum sample by culture.

Materials and Methods: ELISA was performed on serum samples antemortem. In addition, bacteriological culture and PCR were conducted after PM. Tuberculosis infection was identified in humans who had contact with camels using ELISA for serum samples and culture for sputum samples.

Results: Tuberculous lesions were detected in 184 of 10,903 camels (1.7\%). The ELISA results revealed that of the 184 examined camel serum samples, $124(67.39 \%)$ were positive and all 20 camel serum samples that had no associated tuberculous lesions were negative. Moreover, only one of $48(2.08 \%)$ human serum samples was positive by ELISA. Mycobacterial culture revealed 112 isolates from the 184 examined camel samples $(60.87 \%)$, while human sputum sample cultures were all negative. PCR analysis identified the mpb70 gene in three of seven randomly tested samples.

Conclusion: Gene sequencing was performed on two samples and the sequences were submitted to the National Center for Biotechnology Information GenBank (accession numbers MF990289 and MG59479). A phylogenetic tree was constructed based on the partial DNA sequences of the mpb70 gene; the similarity between the isolates was $98.1 \%$. The similarities between the two isolates and the standard strains of Mycobacterium bovis in GenBank were 98.1\% and 100\%, respectively. Further investigation on the antemortem detection of M. bovis infection in camels is needed to decrease public risk.
\end{abstract}

Keywords: camel, enzyme-linked immunosorbent assay, Mycobacterium bovis, polymerase chain reaction, tuberculosis.

\section{Introduction}

The dromedary camels in Africa represent approximately $74 \%$ of the global camel population and serve as an essential source of meat and milk for humans [1].

Tuberculosis (TB) is a chronic, reportable granulomatous zoonosis caused by Mycobacterium tuberculosis complex and affects many animal species including camels $[2,3]$. A high prevalence of camel TB is usually found among farmed camels and those in close proximity to cattle, which are mainly affected

Copyright: Elnaker, et al. Open Access. This article is distributed under the terms of the Creative Commons Attribution 4.0 International License (http://creativecommons.org/licenses/ by/4.0/), which permits unrestricted use, distribution, and reproduction in any medium, provided you give appropriate credit to the original author(s) and the source, provide a link to the Creative Commons license, and indicate if changes were made. The Creative Commons Public Domain Dedication waiver (http:// creativecommons.org/publicdomain/zero/1.0/) applies to the data made available in this article, unless otherwise stated. by Mycobacterium bovis [4,5]. The transmission of M. bovis between animals primarily occurs through aerosols, direct contact, sharing the same food and water, and suckling [6].

Despite continuous eradication programs and milk pasteurization, $M$. bovis is a major public health hazard, especially for people in close contact with infected animals. TB in camel has been diagnosed in many countries including Egypt $[4,7,8]$. Ministry of Health and Population in Egypt is making a great effort for TB elimination by many strategies including early diagnosis and other means [9].

There are many difficulties in diagnosing camel TB in living animals. First, none of the available tests can diagnose camel TB with certainty. Second, the intradermal tuberculin test, which is a classical diagnostic test, often produces non-specific reactions in camelids. Consequently, due to the lack of sufficient tests for live animals, a definitive diagnosis can be made only on postmortem (PM) 
examination $[10,11]$. An ideal test for the diagnosis of camel TB would be performed antemortem and exhibits no false positives due to cross-reactions with environmental mycobacteria [12]. Although the sensitivity of polymerase chain reaction (PCR) may reach $95 \%$, PCR requires tissue samples that are available only PM [13].

An enzyme-linked immunosorbent assay (ELISA) also provides good sensitivity and specificity for the diagnosis of camel TB and could be used as a confirmatory test at slaughter [14]. It is very important to detect camel TB in live animals, consequently decreasing the public health hazard.

The present study aimed to detect the prevalence of $M$. bovis in camels by performing ELISA on camel sera, detecting tuberculous lesions at the PM examination, culturing Mycobacterium, and identifying Mycobacterium with PCR. In addition, DNA sequencing was performed.

\section{Materials and Methods}

\section{Ethical approval and informed consents}

All procedures performed in this study, including the collection of human and animal serum samples, were in accordance with the Egyptian ethical standards of the National Research Committee and the Animal Rights and Ethical Use Committee of Assiut University. All human subjects gave their consent for the collection of the serum samples, with the agreement that any identifying details of the individuals would not be published.

\section{Study area}

This study was conducted in an abattoir in El-Behera Governorate, which is a governorate of Egypt with the capital city of Damanhur, located in the Western Delta.

\section{Animals and humans}

A total of 10,903 camels that were slaughtered at abattoir during the study period from January 2015 to November 2017 underwent serum sample collection and were clinically examined. The characteristics including sex, age, and origin of individual camels were carefully identified. The serum and sputum of humans who had occupational contact with the camels were also sampled. The obtained data revealed that the camels were not previously vaccinated with the Bacille Calmette-Guerin (BCG) vaccine.

\section{Serum samples}

Blood samples were collected from all camels before slaughter and serum separation was performed. The serum samples were preserved at $-20^{\circ} \mathrm{C}$ until use. In addition, samples from humans with occupational contact were collected.

\section{PM examination}

Thorough PM examination was performed following previously described procedures [15].

\section{ELISA}

ELISA was performed on 184 serum samples from camels with tuberculous lesions as well as 20 serum samples from camels without tuberculous lesions. In addition, 48 serum samples were collected from humans with occupational contact (working in the same abattoirs). A Bovine TB Antibody ELISA Kit (Wuhan Unibiotest Co., Ltd.) was used to perform an indirect ELISA for the qualitative detection of $M$. bovis antibodies in serum. The kit contains a microplate that has wells pre-coated with bovine TB antigen; the antigen was also compatible with human serum samples.

\section{Lymph nodes}

A total of 184 tuberculous lesions were aseptically collected from slaughtered camels and placed into sterile universal bottles containing $5 \mathrm{ml}$ of $0.9 \%$ saline solution. The samples were kept in an icebox with solid ice packs and transported to the Animal Health Research Institute TB unit for microbiological cultivation and molecular diagnosis of $M$. bovis.

\section{Human sputum samples}

A total of 48 sputum samples were collected from humans working in the abattoirs of the sampled camels. Samples were transported on ice to the TB unit for Mycobacterium cultivation. Sputum samples were obtained by spontaneous morning expectoration.

\section{Microbiological examination}

The samples were examined for the isolation and identification of $M$. bovis using conventional methods such as direct smear, culture, and biochemistry and molecular methods such as PCR.

\section{Culture technique}

The infected lymph nodes of 184 slaughtered camels and 48 sputum samples from humans were prepared according to the Marks technique [16].

\section{PCR technique}

Seven of 184 randomly collected tuberculous lesions were submitted for PCR analysis; $25 \mathrm{mg}$ of each sample was incubated with $180 \mu$ l of ATL buffer and $20 \mu \mathrm{l}$ of QIAGEN protease and incubated for $3 \mathrm{~h}$ at $56^{\circ} \mathrm{C}$, then $\mathrm{AL}$ buffer was added to the lysate and analysis was performed as in the fluid samples.

\section{DNA extraction}

Sample DNA extraction was performed using a QIAamp DNA Mini Kit (QIAGEN, Germany, GmbH) with modifications of the manufacturer's recommendations. Briefly, $200 \mu 1$ of the sample suspension was incubated with $10 \mu \mathrm{l}$ of proteinase $\mathrm{K}$ and $200 \mu \mathrm{l}$ of lysis buffer at $56^{\circ} \mathrm{C}$ for $10 \mathrm{~min}$. After incubation, $200 \mu \mathrm{l}$ of $100 \%$ ethanol was added to the lysate. The sample was then washed and centrifuged following the manufacturer's recommendations. Nucleic acid was eluted with $100 \mu 1$ of elution buffer provided in the kit. 


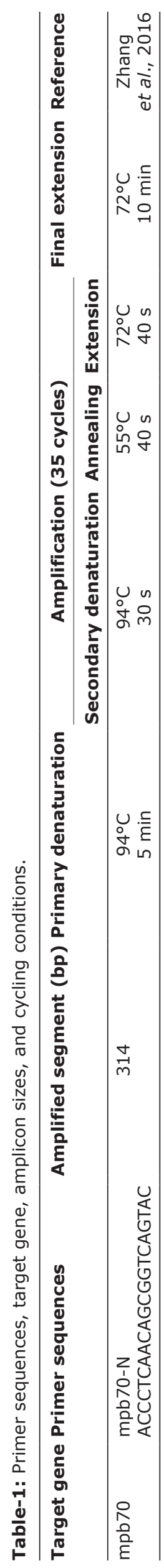

\section{Oligonucleotide primers}

Primers used were supplied from Metabion (Germany) and are listed in Table-1.

\section{PCR amplification}

Primers were utilized in a $25 \mu$ reaction containing $12.5 \mu \mathrm{l}$ of EmeraldAmp Max PCR Master Mix (Takara, Japan), $1 \mu$ l of each primer with 20 pmol concentrations, $4.5 \mu$ l of water, and $6 \mu 1$ of DNA template. The reaction was performed in an Applied Biosystems 2720 thermal cycler.

\section{Analysis of $P C R$ products}

The PCR products were separated by electrophoresis in $1 \times \mathrm{TBE}$ buffer on $1.5 \%$ agarose gel (Applichem, Germany, GmbH) with a $5 \mathrm{~V} / \mathrm{cm}$ gradient at room temperature. For electrophoresis, $15 \mu \mathrm{l}$ of the product was loaded in each gel well. A Gelpilot 100 bp ladder (QIAGEN, Germany, GmbH) was used to determine the fragment sizes. The gel was photographed with a gel documentation system (Alpha Innotech, Biometra), and the data were analyzed with computer software.

\section{Sequence and phylogenetic analyses}

DNA sequencing of the mpb70 gene was conducted in both directions, and a consensus sequence of $314 \mathrm{bp}$ was used for nucleotide (nt) analysis. The original sequences were trimmed to remove vague nt sequences, which usually exist at the beginning of the sequence. Partial DNA sequences were submitted to the GenBank database. Comparisons of the obtained nt sequences with other Mycobacterium sequences published in GenBank were performed using theBioEdit sequence alignment editor (Version 7.0.5) [17] andMegAlign ${ }^{\mathrm{TM}}$, DNASTAR Lasergene ${ }^{\circledR}$, Version 7.1.0, (Lasergene Molecular Biology, USA). Phylogenetic tree reconstruction based on the neighbor-joining method was performed using MegAlign $^{\mathrm{TM}}$ [18]. Sequence divergence and identity percentages were calculated by MegAlign ${ }^{\mathrm{TM}}$.

\section{Statistical analysis}

The Chi-square test was a statistical test used to detect $p$-value. $p \leq 0.01$ typically indicates high significance while $\mathrm{p}>0.01$ indicates no statistical significance.

\section{Results}

\section{PM examination}

Table-2 and Figures- 1 and 2 show that of 10,903 camels, 184 camels had tuberculous lesions (1.69\%), with the highest percentage $(2.5 \%)$ found in 2017 , and the percentage of tuberculous lesions was nearly similar in females and males $(1.7 \%$ and $1.69 \%$, respectively).

Tables-3 and 4 and Figure-3 show that of the 184 examined serum samples from camels with tuberculous lesions, $124(67.39 \%)$ were positive by ELISA, while serum samples from camels without tuberculous lesions were negative. Furthermore, of the 48 humans who had occupational contact with 
Table-2: Percent of tuberculous lesions in slaughtered camels in correlation with age and sex.

\begin{tabular}{|c|c|c|c|c|c|c|c|c|}
\hline \multirow[t]{3}{*}{ Age } & \multicolumn{6}{|c|}{ Year } & \multirow[t]{3}{*}{ Total } & \multirow[t]{3}{*}{ Percentage } \\
\hline & \multicolumn{2}{|c|}{2015} & \multicolumn{2}{|c|}{2016} & \multicolumn{2}{|c|}{2017} & & \\
\hline & $\begin{array}{c}\text { Number of } \\
\text { slaughtered } \\
\text { camel }\end{array}$ & $\begin{array}{l}\text { Number of } \\
\text { TB lesions }\end{array}$ & $\begin{array}{c}\text { Number of } \\
\text { slaughtered } \\
\text { camel }\end{array}$ & $\begin{array}{l}\text { Number of } \\
\text { TB lesions }\end{array}$ & $\begin{array}{c}\text { Number of } \\
\text { slaughtered } \\
\text { camel }\end{array}$ & $\begin{array}{l}\text { Number of } \\
\text { TB lesions }\end{array}$ & & \\
\hline$<5$ years old* & 1014 & $4(0.39 \%)$ & 528 & $3(0.57 \%)$ & 290 & $2(0.69 \%)$ & 1832 & $9(0.59 \%)$ \\
\hline$>5$ years old* & 4386 & $57(1.3 \%)$ & 3472 & $82(2.36 \%)$ & 1213 & $36(2.97 \%)$ & 9071 & $175(1.93 \%)$ \\
\hline Total & 5400 & $61(1.1 \%)$ & 4000 & $85(2.1 \%)$ & 1503 & $38(2.5 \%)$ & 10,903 & $184(1.7 \%)$ \\
\hline \multicolumn{9}{|c|}{ According to sex } \\
\hline Female** & 350 & 4 & 220 & 5 & 135 & 3 & 705 & $12(1.7 \%)$ \\
\hline Male** & 5050 & 57 & 3780 & 80 & 1368 & 35 & 10,198 & $172(1.69 \%)$ \\
\hline Total & 5400 & $61(1.13 \%)$ & 4000 & $85(2.13 \%)$ & 1503 & $38(2.5 \%)$ & 10,903 & $184(1.69 \%)$ \\
\hline
\end{tabular}

*This result is significant at $\mathrm{p}<0.01$. **This result is not significant at $\mathrm{p}<0.01$. ELISA=Enzyme-linked immunosorbent assay
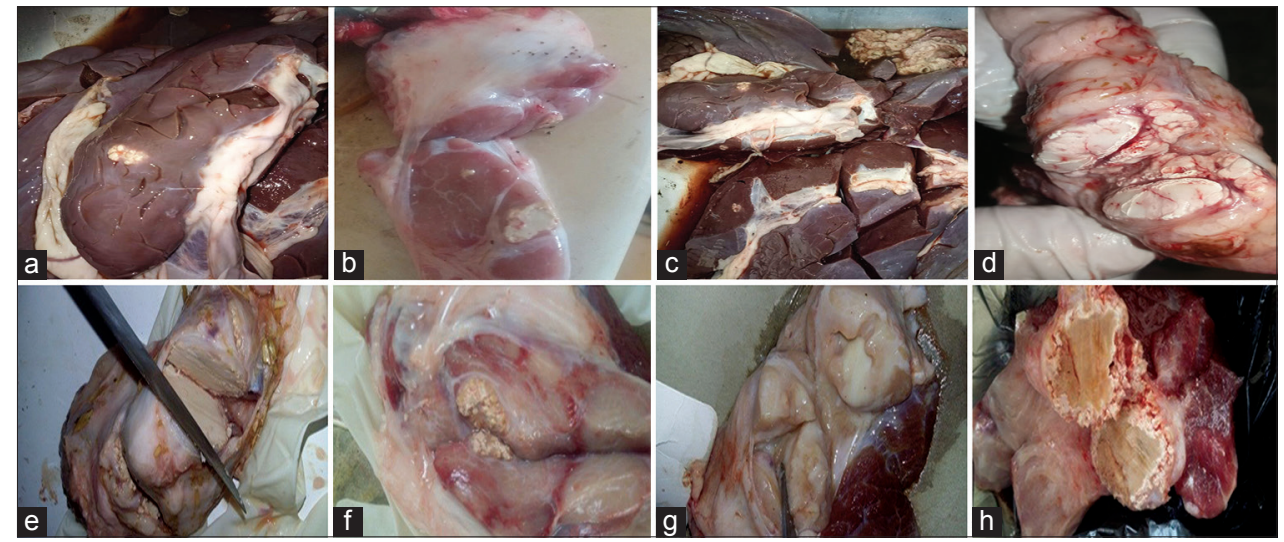

Figure-1: (a-h) Tuberculous lesions in different organs of camels.

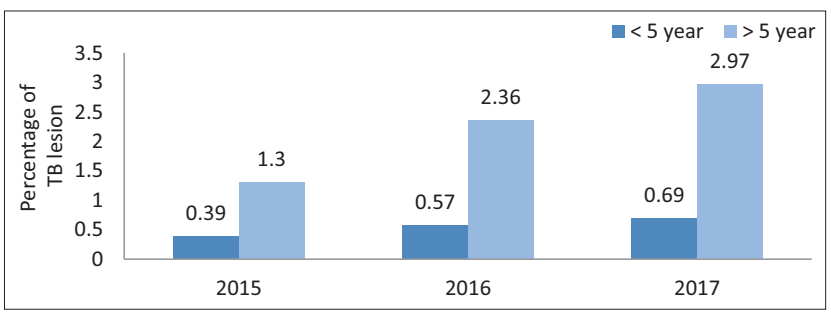

Figure-2: Percent of tubercles lesion detected in slaughtered camels in correlation with age.

camels, only one serum sample $(2.08 \%)$ was positive by ELISA. Mycobacterium culture revealed 112 isolates from 184 camel samples (60.87\%); however, all human sputum sample cultures were negative.

Regarding age as a risk factor, the prevalence of M. bovis detected in camels aged over 5 years was $70.29 \%$ and $64 \%$ by ELISA and culture, respectively. In camels aged $<5$ years, $M$. bovis was negative in all cultures, and one of 9 serum samples (11.11\%) was positive by ELISA.

The PCR results revealed that three samples were positive for the mpb70 gene (Figure-4), and the purified PCR product for two isolates was subsequently sequenced and analyzed. The sequence was submitted to the National Center for Biotechnology Information (NCBI) GenBank (accession numbers MF990289 and MG59479). The phylogenetic tree was built with the partial DNA sequences of the mpb70 gene from two $M$. bovis isolates with standard strains (Figures-5 and 6); the isolates showed 98.1\% sequence similarity. Moreover, the similarities between the two isolates and the standard strains of M. bovis (ATCC BAA-935 and BCG-ATCC 35743) were $98.1 \%$ and $100 \%$.

\section{Discussion}

Traditional culture and PM examination methods are the current procedures for TB detection and control. Several studies on camel TB have been conducted in several countries, including Egypt, confirming the occurrence of TB in camel populations [19,20].

The prevalence of TB in camels based on PM examination was $1.69 \%$ (Table-2 and Figure-2). Higher TB prevalence rates than those obtained in this study were obtained by Beyi et al. [21], who reported a prevalence rate of $8.3 \%$, Narnaware et al. [22], who reported 19.56\%, Jibril et al. [23], who reported 9.82\%, and Ahmad et al. [24], who reported 33.5\%. On the other hand, a lower TB rate in Egypt than that obtained in this study was reported by Manal and Gobran [7], who concluded that the prevalence of TB in camels was $0.7 \%$. The difference in prevalence rates may be attributed to the number of samples collected. We agree that in infected camels reared with cattle or beside cattle farms, the isolated strain is mainly M. bovis. 
Of the 184 examined camels, serum samples from 124 camels $(67.39 \%)$ were positive by ELISA, while camels with no lesions were negative by ELISA. Furthermore, one of 48 (2.08\%) serum samples from the humans who had occupational contact with camels was positive, while human sputum sample cultures were all negative (extrapulmonary TB and osseous TB). Majority of human infections with $M$. bovis is mainly expressed as extrapulmonary manifestations $[25,26]$.

Manal and Gobran [7] and ElNaker et al. [27] confirmed that the ELISA technique is an efficient technique for TB diagnosis and can be used for serological TB monitoring in Egypt. In this study, ELISA revealed one serum sample that was positive for TB in a young camel; Phillips et al. [28] indicated that colostrum may contain a very high dose of Mycobacterium that can result in infection in young camels, similar to cattle, possibly explaining the result in this study.

There are several studies that describe the prevalence of M. bovis in humans; Aliyu et al. [29] detected

Table-3: Prevalence of $M$. bovis by ELISA and culture.

\begin{tabular}{lcccc}
\hline Species & Total & ELISA & & $\begin{array}{c}\text { Mycobacterium } \\
\text { culture }\end{array}$ \\
\cline { 3 - 3 } \cline { 5 - 5 } & & Positive (\%) & Positive (\%) \\
\hline $\begin{array}{l}\text { Camels with } \\
\text { tubercle lesions }\end{array}$ & 184 & $124(67.39)$ & & $112(60.87)$ \\
$\begin{array}{l}\text { Camel without } \\
\text { tubercle lesions }\end{array}$ & 20 & $0(0)$ & & - \\
Abattoir workers & 48 & $1(2.08)$ & & $0(0)$ \\
\hline
\end{tabular}

M. bovis=Mycobacterium bovis, ELISA=Enzyme-linked immunosorbent assay a prevalence rate of $0.2 \%$ in Nigeria and Diagbouga et al. [30] detected a prevalence rate of $6.2 \%$ in Burkina Faso. The failure to isolate M. bovis from sputum samples in this study does not dismiss the importance of zoonotic TB. A sputum culture is a gold standard for the diagnosis of pulmonary TB; however, the accurate diagnosis of extrapulmonary TB is complex and difficult [31].

PCR has been described as an important tool for the diagnosis of bovine TB since it is a rapid, accurate, sensitive, and efficient method and can be used in the epidemiological characterization of animals infected with bovine TB [32]. In addition, PCR avoids the problems associated with attempting cultivation of this slow-growing group of bacteria in culture. Consequently, it is considered an important tool for zoonotic TB control [33]. Mpb70 is one of the most well-studied mycobacterial antigens and an extremely homologous protein within the M. tuberculosis complex; it is also a major antigen widely expressed by $M$. bovis, but significantly less frequently expressed by $M$. tuberculosis [34,35]. The presence of M. bovis was confirmed and purified DNA product of two isolates was sequenced and analyzed. The sequences were submitted to NCBI GenBank (accession numbers MF990289 and MG59479). The phylogenetic tree was constructed based on the partial mpb70 gene sequences of the two isolates with a standard strain and another $M$. bovis strain published in GenBank (Figure-6). The isolates showed $98.1 \%$ sequence identity to one another. Moreover, the sequences of the isolates showed $98.1 \%$ and $100 \%$ identity with

Table-4: Prevalence of $M$. bovis by age.

\begin{tabular}{lcccccc}
\hline Species & \multirow{2}{*}{ Age } & \multicolumn{2}{c}{ ELISA from serum } & & \multicolumn{2}{c}{ Mycobacterium culture from lesion } \\
\cline { 3 - 4 } & & Examined & Positive (\%) & & Examined & Positive (\%) \\
\hline Camels & $<5$ years & 9 & $1(11.11)$ & & 9 & 0 \\
Total & $>5$ years & 175 & $123(70.29)$ & & 175 & $112(64)$ \\
\hline
\end{tabular}

M. bovis=Mycobacterium bovis, ELISA=Enzyme-linked immunosorbent assay



Figure-3: Comparison of enzyme-linked immunosorbent assay results from serum samples and Mycobacterium culture of tubercle lesions from camels and sputum from humans. 
that of $M$. bovis standard strains ATCCBAA 935 and BCG ATCC35743.

\section{Conclusion}

The prevalence of TB in camels in the Delta region is increasing annually. Strict hygienic regulations for camel importation as well as new tools should be used for TB detection, especially in live camels, to control and confirm infection. The general public should be intensely warned

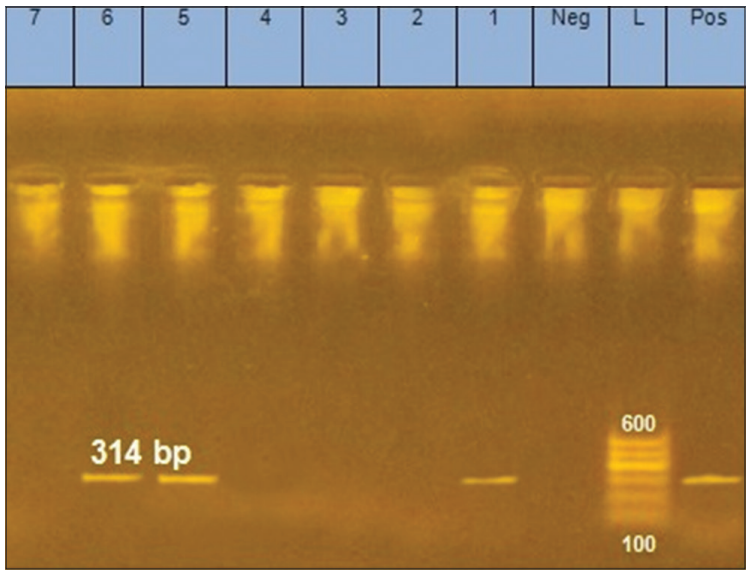

Figure-4: Gel electrophoresis of polymerase chain reaction products and the mpb70 gene. L: Ladder; Lanes 1, 5 and 6: Amplified products prepared from infected lymph nodes; Lanes 2, 3, 4 and 7: Negative samples. against consuming meat from unauthorized slaughterhouses. These approaches will improve the prevention and control of the bovine TB program in Egypt, resulting in a positive impact on human public health.

\section{Authors' Contributions}

YFE, MSD, AE, RSZ, and NAI conceived and designed the experiments. NAI, MSD, AR, and RSZ performed the experiments. YFE and RSZ analyzed the data. AE and NAI contributed reagents/materials/ analysis tools. MSD and YFE wrote the paper. All authors read and approved the final manuscript.

\section{Acknowledgments}

The authors would like to thank staff members of abattoir of El-Behira Province and staff member TB unit, Animal Health Research Institute, Dokki, Egypt, for their support the conduction of the research. The authors did not receive any fund for this study.

\section{Competing Interests}

The authors declare that they have no competing interests.

\section{Publisher's Note}

Veterinary World remains neutral with regard to jurisdictional claims in published institutional affiliation.

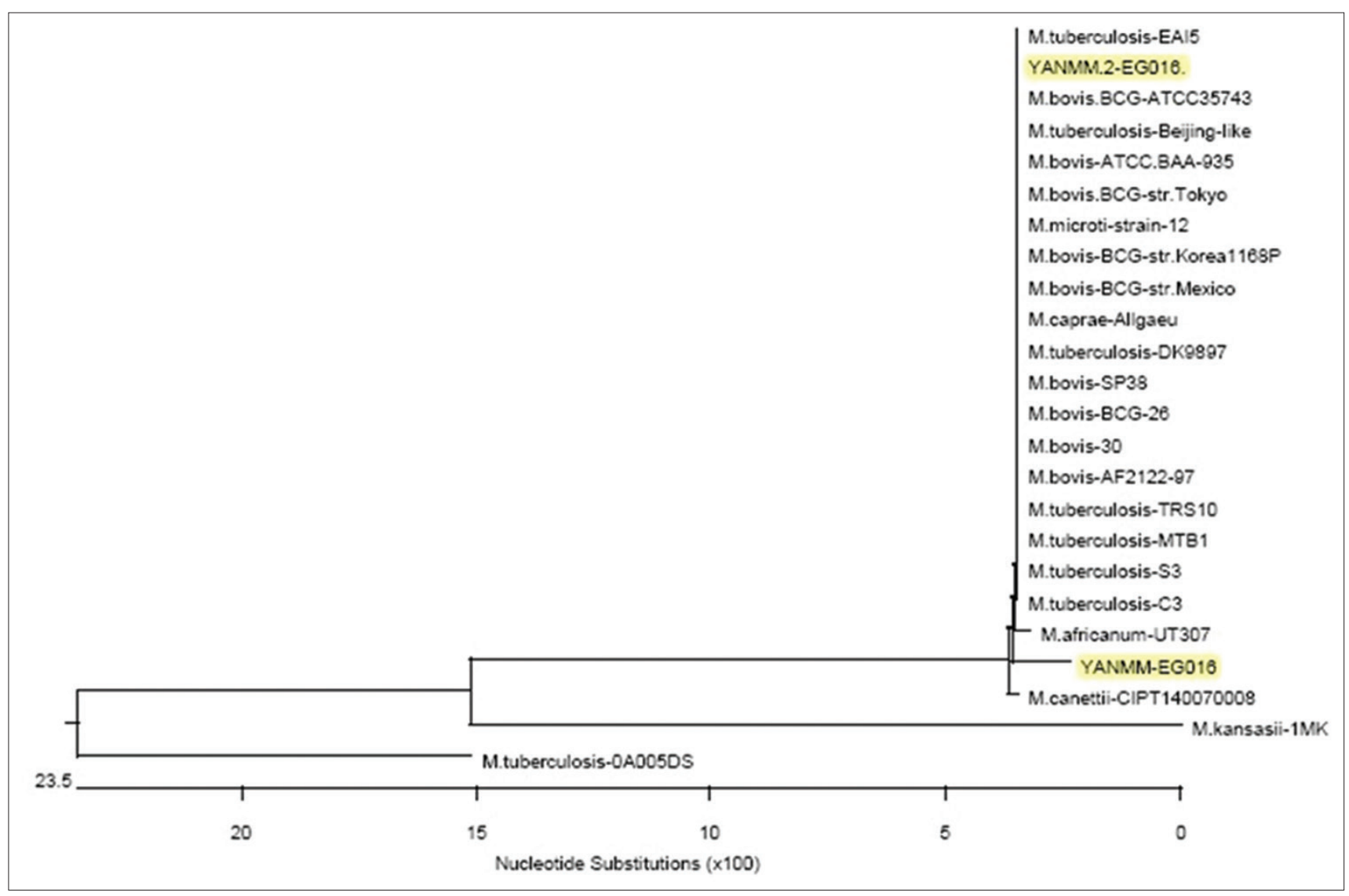

Figure-5: Phytogenic analysis of Mycobacterium bovis isolates based on mpb70 gene sequencing. 


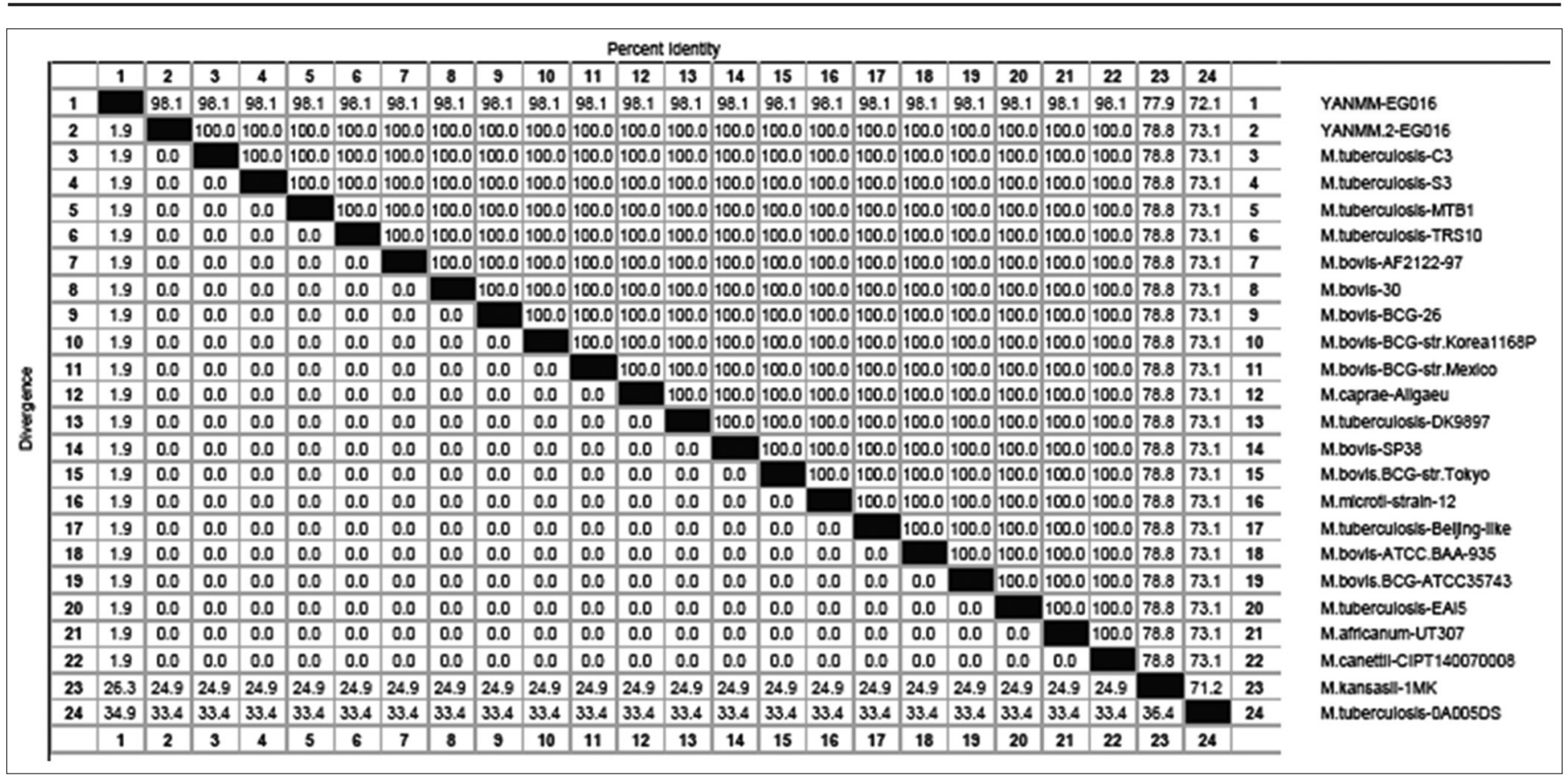

Figure-6: Sequence identity and divergence between various isolates of Mycobacterium bovis.

\section{References}

1. Rhodes, S., Crawshaw, T., de la Rua-Domenech, R., Bradford, S., Lyashchenko, K.P., Mamo, G., Summers, D., Wernery, U. and Zanolari, P. (2015) Mycobacterial Infections in Camelids. CABI, Oxfordshire. p216-234.

2. Thoen, C.O., Steele, J.H. and Kaneene, J.B. (2014) Zoonotic Tuberculosis: Mycobacterium bovis and Other Pathogenic Mycobacteria. John Wiley and Sons, Ames, Iowa.

3. OIE. (2016) Bovine Tuberculosis in OIE Terrestrial Animal Health Manual. Ch. 11, 5. OIE, France. p586-589.

4. Twomey, D., Higgins, R., Worth, D., Okker, M., Gover, K., Nabb, E. and Speirs, G. (2010) Cutaneous TB caused by Mycobacterium bovis in a veterinary surgeon following exposure to a tuberculous alpaca. Vet. Rec., 166(6): 175-177.

5. Bennett, J.E., Dolin, R. and Blaser, M.J. (2014) Mandell, Douglas, and Bennett's Principles and Practice of Infectious Diseases. Vol. 2. Elsevier Health Sciences, US.

6. El-Sayed, A., El-Shannat, S., Kamel, M., CastañedaVazquez, M. and Castañeda-Vazquez, H. (2016) Molecular epidemiology of Mycobacterium bovis in humans and cattle. Zoonoses Public Health, 63(4): 251-264.

7. Manal, M.Y. and Gobran, R. (2008) Some studies on tuberculosis in camel. Egypt. J. Comp. Pathol. Clin. Pathol., 21(4): 58-74.

8. Mustafa, I. (2013) Bacterial diseases of dromedaries and Bactrian camels. Rev. Sci. Tech. Int. Epizoot., 6(2): 391-405.

9. Ministry of Health and Population. (2017) Tuberculosis Control Guidelines. Ministry of Health and

Population, Nepal.

10. Alvarez, G.G., Gushulak, B., Rumman, K.A., Altpeter, E., Chemtob, D., Douglas, P., Erkens, C., Helbling, P., Hamilton, I., Jones, J., Matteelli, A., Paty, M.C., Posey, D.L., Sagebiel, D., Slump, E., Tegnell, A., Valín, E.R., Winje, B.A. and Ellis, E. (2011) A comparative examination of tuberculosis immigration medical screening programs from selected countries with high immigration and low tuberculosis incidence rates. BMC Infect. Dis., 11(1): 3 .

11. Thoen, C.O., Kaplan, B., Thoen, T.C., Gilsdorf, M.J. and Shere, J.A. (2016) Zoonotic tuberculosis. A comprehensive one health approach. Medicina (Buenos Aires), 76(3): 159-165.

12. Marassi, C., Medeiros, L., McNair, J. and Lilenbaum, W. (2011) Use of recombinant proteins MPB70 or MPB83 as capture antigens in ELISAs to confirm bovine tuberculosis infections in Brazil. Acta Trop., 118(2): 101-104.

13. Lilenbaum, W., Pessolani, M. and Fonseca, L. (2001) The use of Ag85 complex as antigen in ELISA for the diagnosis of bovine tuberculosis in dairy cows in Brazil. J. Vet. Med. B Infect. Dis. Vet. Public Health, 48(3): 161-166.

14. Cousins, D. and Florisson, N. (2005) A review of tests available for use in the diagnosis of tuberculosis in non-bovine species. Rev. Sci. Tech., 24(3): 1039-1059.

15. Smith, B. (2009) Large Animal Internal Medicine. Mosby Inc., An Affiliate of Elsevier Inc., St. Louis. p873-897.

16. Ratledge, C. and Stanford, J. (1982) The Biology of the Mycobacteria. Academic Press, London.

17. Hall, T.A. (1999) BioEdit: A User-friendly Biological Sequence Alignment Editor and Analysis Program for Windows 95/98/NT. Nucleic Acids Symposium Series. Information Retrieval Ltd., London. pc1979-c2000.

18. Thompson, J.D., Higgins, D.G. and Gibson, T.J.A. (1994) CLUSTAL W: Improving the sensitivity of progressive multiple sequence alignment through sequence weighting, position-specific gap penalties and weight matrix choice. Nucleic Acids Res., 22(22): 4673-4680.

19. Koni, A., Juma, A., Morini, M., Nardelli, S., Connor, R. and Koleci, X. (2016) Assessment of an ELISA method to support surveillance of bovine tuberculosis in Albania. Ir. Vet. J., 69(1): 11 .

20. Fassi-Fehri, M. (1987) Diseases of camels. Rev. Sci. Tech. Int. Epizoot., 6(2): 337-354.

21. Beyi, A.F., Gezahegne, K.Z., Mussa, A., Ameni, G. and Ali, M.S. (2014) Prevalence of bovine tuberculosis in dromedary camels and awareness of pastoralists about its zoonotic importance in Eastern Ethiopia. J. Vet. Med. Anim. Health, 6(4): 109-115.

22. Narnaware, S.D., Dahiya, S.S., Tuteja, F.C., Nagarajan, G., Nath, K. and Patil, N.V. (2015) Pathology and diagnosis of Mycobacterium bovis in naturally infected dromedary camels (Camelus dromedarius) in India. Trop. Anim. Health Prod., 47(8): 1633-1636.

23. Jibril, Y., Mamo, G., Hanur, I., Zewude, A. and Ameni, G. (2016) Prevalence of camel tuberculosis and associated risk factors in camels slaughtered at Akaki Abattoir, Ethiopia. Ethiop. Vet. J., 20(1): 23-38.

24. Ahmad, I., Kudi, C.A., Babashani, M., Chafe, U.M., Yakubu, Y.A. and Shittu, A. (2019) Tuberculosis in dromedary camels slaughtered in Nigeria: A documentation of lesions at postmortem. Trop. Anim. Health Prod., 
51(1): 73-78.

25. Malama, S., Johansen, T.B., Muma, J.B., Munyeme, M., Mbulo, G., Muwonge, A., Djønne, B. and Godfroid, J. (2014) Characterization of Mycobacterium bovis from humans and cattle in Namwala district, Zambia. Vet. Med. Int., 2014:1-7

26. Han, P., Orta, P., Kwon, D.I. and Inman, J.C. (2015) Mycobacterium bovis cervical lymphadenitis: A representative case and review. Int. J. Pediatr. Otorhinolaryngol., 79(11): 1798-1801.

27. Elnaker, Y.F., ElSharawy, N.T., Daib, M.S., ElGedawy, A.A. and Ibrahim, N.A. (2018) Conventional and molecular detection of Mycobacterium bovis in Aburden angus cattle and human contact in the new valley governorate, Egypt. Assiut Vet. Med., 64(157): 179-186.

28. Phillips, C., Foster, C., Morris, P. and Teverson, R. (2003) The transmission of Mycobacterium bovis infection to cattle. Res. Vet. Sci., 74(1): 1-15.

29. Aliyu, G., El-Kamary, S.S., Abimiku, A., Brown, C., Tracy, K., Hungerford, L. and Blattner, W. (2013) Prevalence of non-tuberculous mycobacterial infections among tuberculosis suspects in Nigeria. PLoS One, 8(5): e63170.

30. Diagbouga, S., Nadembèga, C., Tarnagda, Z., Djibougou, A., Henry, N., Bicaba, R.T., Dembélé, M.,
Combary, A., Diandé, S. and Ouédraogo, M. (2017) Mycobacterium bovis prevalence in humans does not differ between regions in Burkina Faso. Arch. Clin. Microbiol., $8(1)$.

31. World Health Organization. (2007) Improving the Diagnosis and Treatment of Smear-negative Pulmonary and Extrapulmonary Tuberculosis among Adults and Adolescents: Recommendations for HIV-prevalent and Resource-constrained Settings. World Health Organization, Geneva.

32. Ishaga, H.Z., Mukhtarc, M.M. and Bakheitc, S.M. (2015) Molecular detection of bovine tuberculosis in El Rank area, North Upper Nile State, Sudan. Sci. Lett., 3(1): 23-26.

33. Asebe, G. (2017) Molecular characterization of Mycobacterium bovis and its significance: Role for control of zoonotic tuberculosis in Africa. J. Med. Diagn. Methods, 6(3): 2-10.

34. Wiker, H. (2009) MPB70 and MPB83 major antigens of Mycobacterium bovis. Scand. J. Immunol., 69(6): 492-499.

35. Zhang, H., Wang, Z., Cao, X., Wang, Z., Sheng, J., Wang, Y., Zhang, J., Li, Z., Gu, X. and Chen, C. (2016) Loop-mediated isothermal amplification assay targeting the mpb70 gene for rapid differential detection of Mycobacterium bovis. Arch. Microbiol., 198(9): 905-911. 